\title{
（地独）東京都立産業技術研究センターにおける表面分析依頼試験
}

\author{
三尾 淳 ${ }^{\mathrm{a}}$, 木下 稔夫 ${ }^{\mathrm{b}}$, 上野 博志 ${ }^{\mathrm{c}}$
}

\section{Analysis Services on Surface Finishing in Tokyo Metropolitan Industrial Technology Research Institute}

\author{
Atsushi MITSUO ${ }^{a}$, Toshio KINOSHITA ${ }^{b}$ and Hiroshi UENO
}

\section{1. はじめに ${ }^{1)}$}

東京都内の製造業は, 社会環境の変化に加え, 地価や人件 費等の事業コスト及び住工接近などの影響を受けて顕著な減 少傾向にある。近年では, 事業所数, 従業者数, 出荷額等, 付加価值額のいずれにおいても最盛期から 3 割以上の減少と なっている。それでも，長く工業の集積地であることから生 産用機械やその部分品など高度な技術を要する産業や, 文化 の発信地であることから伝統工芸品産業など，特徵のある製 造業が多く存在する。また, 比較的小規模な事業所が多いこ とも特徴で, 平成 20 年の事業所数は全国で 2 位であるが, 出荷額等及び従業者数はそれぞれ 10 位及び 6 位である。全 国比で出荷額が多いのは印刷・同関連業，情報通信機械，皮 革・同製品となっている。

中分類別事業所数には地域性があり，表 1 に示すようにそ れぞれ業種に特徵がある。都心及び副都心ではほぼ印刷・同 関連業が占めている。他の地域では突出した業種はないが, 瀻維工業や金属製品などで，それぞれの地域に集積している 業種がある。事業所数は区部で多くなっており, 特に城東地 域では，区部で最大の事業所数を擁する城南地域の 3 倍近く

表 1 東京都の地域別 · 中分類別事業所数(製造業，平成 20 年)

\begin{tabular}{|c|c|c|c|}
\hline 地域 & 地域別区域 & 事業所数 & 上位 3 業種 \\
\hline 都心 & 千代田, 中央, 港 & 1,373 & $\begin{array}{l}\text { 印刷・同関連業, 緎維工業, } \\
\text { 食料品 }\end{array}$ \\
\hline 副都心 & 新宿, 文京, 渋谷, 豊島 & 2,671 & $\begin{array}{l}\text { 印刷 ·同関連業, 繊維工業, } \\
\text { 業務用機械 }\end{array}$ \\
\hline 城東 & $\begin{array}{l}\text { 台東, 墨田, 江東, 荒川, } \\
\text { 足立, 葛飾, 江戸川 }\end{array}$ & 18,775 & $\begin{array}{l}\text { 金属製品, 印刷 - 同関連業, } \\
\text { 皮革·同製品 }\end{array}$ \\
\hline 城西 & $\begin{array}{l}\text { 世田谷, 中野, 杉並, 練 } \\
\text { 馬 }\end{array}$ & 1,782 & $\begin{array}{l}\text { 印刷 ·同関連業, 緎維工業, } \\
\text { 金属製品 }\end{array}$ \\
\hline 城南 & 品川, 目黒, 大田 & 6,345 & $\begin{array}{l}\text { 生産用機械, 金属製品, 電 } \\
\text { 気機械 }\end{array}$ \\
\hline 城北 & 北, 板橋 & 2,926 & $\begin{array}{l}\text { 印刷 ·同関連業, 金属製品, } \\
\text { 業務用機械 }\end{array}$ \\
\hline 多摩 & 市部, 郡部 & 6,155 & $\begin{array}{l}\text { 生産用機械, 金属製品, 電 } \\
\text { 気機械 }\end{array}$ \\
\hline 島しょ & （伊豆諸島，小箁 & 110 & 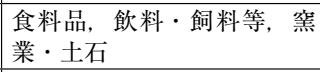 \\
\hline & 合 計 & 40,137 & \\
\hline
\end{tabular}

(地独) 東京都立産業技術研究センター ( ₹ 135-0064 東京都江 東区青海 2-4-10)

URL http://www.iri-tokyo.jp/
である。しかし，区部の平均従業者数は 7.5 人で, 多摩地域 市部の平均従業者数 25.3 人に比べて少なく, 区部の多くは 小規模事業者である。全国と比較しても，東京の事業所は 10 人未満が多く, $81.4 \%$ (全国平均では $69.3 \%$ ) となっている。 さらに, 従業者数 3 人未満の事業所の事業所数, 従業者数, 出荷額等は全国で 1 位であり，東京には比較的付加価值の高 い小規模の製造業が多いことがわかる。

また, 新事業分野については, 新エネルギー・環境関連及 び健康・医療・福祉関連への関心が高く，大都市らしさが現 れている。

これらの背景をふまえ，地方独立行政法人東京都立産業技 術研究センター(以下,「都産技研」という)では, 地域性や 利用者のニーズに応えるべく，区部に本部及び 3 支所，多摩 地域に 1 拠点を配して事業展開をしている。

独法化後の技術相談件数及び依頼試験件数の推移を図 1 に 示す。この間, 経済情勢や社会環境の変化, 本部移転にも関 わらず両者とも増加傾向となっている。これは幅広い業種に 対応していること, 開発型企業のご利用が比較的多いこと, そして都産技研の特徴的な試験である照明試験, 音響試験, ガラス試験などをブランド試験として積極的に実施している こと，などが要因と考えている。

平成 24 年度の技術支援においては，技術相談 124,413 件, 依頼試験件数 137,791 件であった ${ }^{2), 3) 。 ~}$

\section{2. 都産技研の沿革・組織}

2. 1 沿 革 ${ }^{4), 5)}$

都産技研の歴史は大正 10 年 10 月に, 渋沢栄一を会長とし

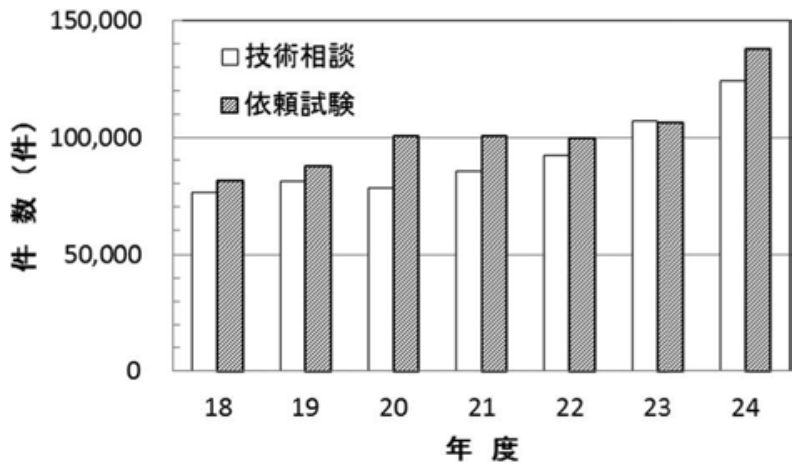

図 1 都産技研の技術相談及び依頼試験の件数推移 
た実業組合の会員らの寄付を元に設立された東京府立東京商 工奨励館 (東京都立工業奨励館の前身) までさかのぼる。その 後, 工業指導機関設置の要請に応えて昭和 13 年より機械部, 化学部，工芸部，などからなる工業奨励館が芝区海岸通り一 丁目(現在の港区海岸一丁目)に建設されて業務を開始し，翌 年に東京商工奨励館の工業試験部が移管されている。

昭和 45 年 12 月には, 東京都立工業奨励館と東京都電気研 究所 (大正 13 年設立) 統合し, 東京都立工業技術センター として北区西が丘に設立された。この背景には，両機関の老 朽化や立地条件の変化, 技術革新にともなう再整備の必要性 などがあった。平成 3 年及び平成 8 年には, 支所としての機 能を持つ東京都城東地域中小企業振興センター(暮飾区青戸) 及び東京都城南地域中小企業振興センター (大田区南蒲田)が それぞれ発足した。

平成 9 年 4 月, 東京都立工業技術センターと東京都立アイ ソトープ総合研究所 (昭和 34 年設立) 統合し，東京都立産 業技術研究所に組織改正された。このとき, 分散していたド ライプロセスなど表面改質，めっき，塗装の各技術分野を集 約して表面技術グループが発足した。

平成 12 年 4 月, 東京都立産業技術研究所に東京都立瀻維 工業試験場が統合された。

平成 14 年 4 月, 暫定の多摩地域拠点として多摩中小企業 振興センターが発足した。

平成 18 年 4 月より，地方独立行政法人東京都立産業技術 研究センターに移行した。このとき, 城東地域中小企業振興 センター, 城南地域中小企業振興センター, 多摩中小企業振 興センターの技術支援部門を同時に法人に加えた。同時期に 岩手県工業技術センターが特定型で地方独立行政法人化して いるが，都産技研は一般型として独法化しており，各種の法 的整備や身分切替等で多くの労力を割いた。

平成 22 年 2 月に多摩地域の拠点として多摩テクノプラザ (昭島市東町)を開設し，多摩支所及び八王子支所を閉鎖した。

平成 23 年 10 月本部 (江東区青海)が開設され，西が丘本部 を閉鎖した。当初は 4 月に開設予定であったが，東日本大震 災の影響により半年間延期となった。これをもって都産技研 の拠点整備が一段落し， 1 本部 1 拠点 3 支所の体制が整った。 図 2 に，都産技研の本部の外観を示す。

\section{2 組 織}

都産技研では，理事長，理事 2 名，監事の 4 名の役員のも と，9つの部に分かれて 300 名余りの職員が運営している。

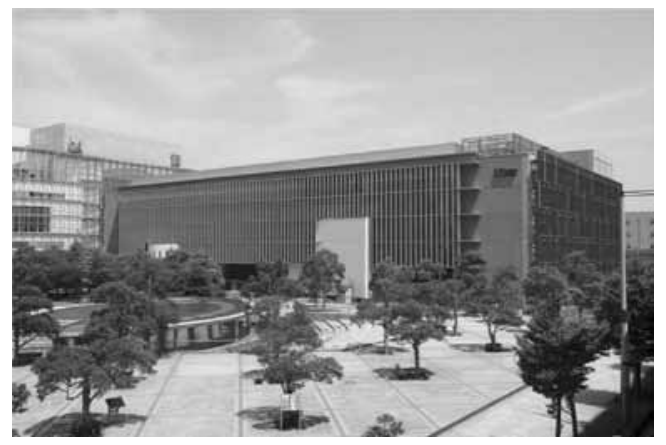

図 2 平成 23 年に開設した本部(江東区青海)

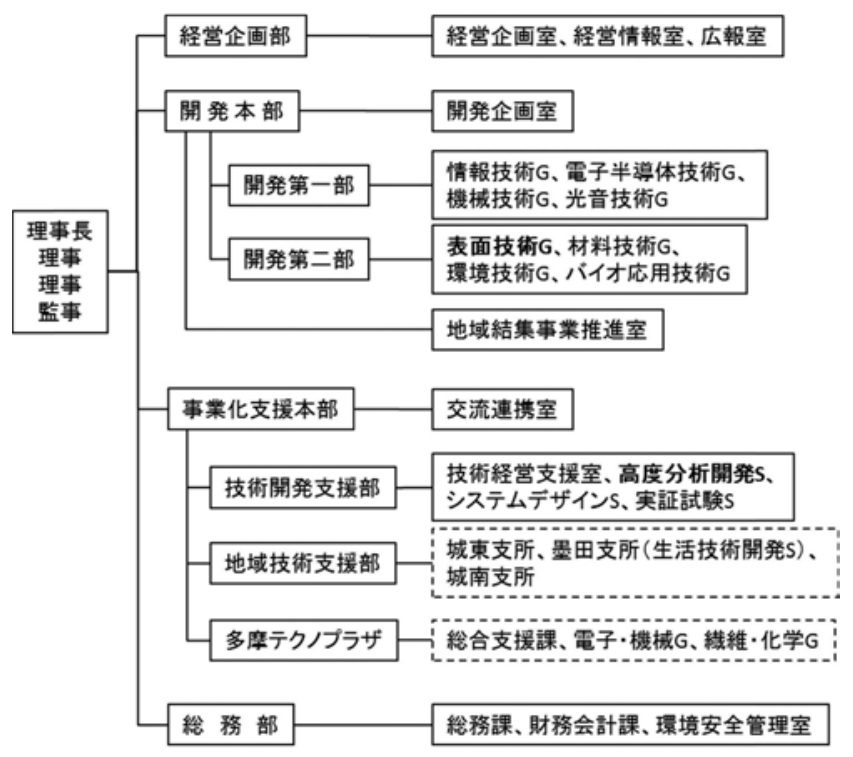

注1)実線は本部所属

注2)Gはグループ、Sはセクターを表す

図 3 都産技研の組織図(平成 25 年 4 月)

このうち, 研究員の数はおよそ 200 名である。図 3 に, 平成 25 年 4 月現在の組織の概要を示す。各研究グループ，セク ター, 室, 課のうち, 実線の枠で示した部署は本部所属であ ることを表す。

依頼試験，研究及び技術支援を実施しているのは，開発第 一部, 開発第二部及び多摩テクノプラザの各研究グループと, 技術開発支援部の各セクター, 及び地域技術支援部の各支所 である。

\section{3. 表面技術関連の分析依頼試験}

表面技術に関連した依頼試験を多種行っているのは，開発 第二部の表面技術グループと技術開発支援部の高度分析開発 セクターである。

\section{1 表面技術グループ}

表面技術グループは，産業に利用される表面処理に関する 技術に特化し，表面改質，めっき，塗装の 3 つの加工技術部 門で構成されている。それぞれ主に下記の分野を担当してい る。

(1)表面改質分野：PVD 法及びCVD 法による薄膜形成,

イオン注入による表面改質

(2)めっき分野：電気めっき，無電解めっき

(3)塗装分野：工業塗装，木工塗装，建築塗装，漆工芸に 関する塗装

表 2 に, 各分野で対応している主な依頼試験を試験機器と ともに示す。これらの試験機器の一部は, 機器利用として立 ち会い試験可能なものもある。

表面技術グループで所管している機器類は各分野に特有の ものが多い。同一の試験機を用いることが多い加工分野であ るが, 試験方法の相違などにより複数機種で対応している試 験項目もある。たとえば，めっき及び塗装分野では複数の摩 耗試験機等を所有しているが，JIS 規格の試験条件等が異な る場合がありそれぞれに対応する試験機を用いている。めっ 
き及び塗装分野の依頼試験は，めっき及び塗装皮膜の物性, 長期耐久性，視覚特性などを中心に実施しており，品質管理， 品質向上, 不良原因解析に寄与している。表面改質分野では 規格化された試験が少ないが，ドライコーティング皮膜の機 械的性質をボールオンディスク摩擦試験機や超微小押込み硬 さ試験機により，及び表面分析を顕微レーザーラマン分光装 置(特に炭素系の皮膜について)などにより依頼試験として実 施している。

\section{2 高度分析開発セクター}

高度分析開発セクターには，一層の高機能化・小型化・高 集積化や極微量化に対応するため, 高機能な測定装置・分析 装置を集中配置している。得られた測定・分析の結果を製品 の不具合原因解析などに活用していただくことで，高精度・ 高付加価値製品の技術課題の解決や技術開発を支援している。

表 2 表面技術グループの各分野における主な依頼試験

\begin{tabular}{|c|c|c|}
\hline 分野 & 目的. 内容 & 試験機器 \\
\hline \multirow{3}{*}{ 表面改質 } & 機械的特性評価 & \begin{tabular}{|l} 
スクラッチ試験機 \\
ボールオンディスク摩擦試験機 \\
超微小押込み硬さ試験
\end{tabular} \\
\hline & 表面分析 & \begin{tabular}{|l} 
走查電子顕微鏡 \\
㫫微レーザーラ分光装置 \\
走查プローブ顕微鏡 \\
$\mathrm{X}$ 線回折装置
\end{tabular} \\
\hline & 表面加工, 改質 & $\begin{array}{l}\text { 集束イオンビーム加工機 } \\
\text { イオン注入装置 } \\
\end{array}$ \\
\hline \multirow{5}{*}{ めっき } & 皮膜の厚さ測定 & 蛍光 X 線膜厚計 \\
\hline & \begin{tabular}{|l}
$\begin{array}{l}\text { 皮膜の厚さ測定 } \\
\text { 及び組織観察 }\end{array}$ \\
\end{tabular} & 光学顕微鏡 (マイクロスコープ) \\
\hline & 皮膜の組成分析 & $\begin{array}{l}\text { エネルギー分散型 X 線分析装置 } \\
\text { 走查電子顕微鏡 } \\
\end{array}$ \\
\hline & 皮膜の物性試験 & $\begin{array}{l}\text { 往復摺動摩耗試験機 } \\
\text { テーバー式摩耗試験機 }\end{array}$ \\
\hline & 皮膜の長期耐久性試験 & $\begin{array}{l}\text { 塩水噴霧試験機 } \\
\text { 複合サイクル試験機 }\end{array}$ \\
\hline \multirow{6}{*}{ 塗装 } & 塗料性状試験 & E 型回転粘度計 \\
\hline & 塗膜の膜厚測定 & $\begin{array}{l}\text { 電磁及びうず電流式膜厚計 } \\
\text { 破式膜厚計 } \\
\text { 光学顕微鏡 (マイクロスコープ) }\end{array}$ \\
\hline & 塗膜の視覚特性 & \begin{tabular}{|l|} 
光沢度計 \\
色彩色差計
\end{tabular} \\
\hline & $\begin{array}{l}\text { 塗膜の } \\
\text { 機械的性質評価 }\end{array}$ & \begin{tabular}{|l} 
衝撃変形試験機 \\
テーバー式摩耗試験機 \\
耐カッピングン性試験機 \\
引張試験機 \\
耐屈曲性試験機
\end{tabular} \\
\hline & 塗膜の化学的性質評価 & 恒温槽 \\
\hline & $\begin{array}{l}\text { 塗膜の } \\
\text { 長期耐久性試験 }\end{array}$ & $\begin{array}{l}\text { 恒温恒湿試験機 } \\
\text { 塩水噴霧試験機 } \\
\text { 複合サイクル試験機 } \\
\text { 促進耐候試験機 }\end{array}$ \\
\hline
\end{tabular}

表 3 高度分析開発セクターの各分野における主な試験機器

\begin{tabular}{c|l}
\hline 分野 & \multicolumn{1}{|c}{ 試験機器 } \\
\hline & 核磁気共鳴分析装置 \\
& ICP 質量分析装置 \\
& X 線光電子分光分析装置 \\
化学計測 & 集束イオンビーム装置 \\
& RBS/ERDA 装直 \\
& 二次イオン質量分析装置 \\
& 透過電子顕微鏡 \\
& 走査電子顕微鏡 \\
\hline & 三次元座標測定機 \\
& 超高精度形状測定機 \\
& 走査型白色干渉計 \\
& レーザー干渉計 \\
& 真円度測定機 \\
\hline
\end{tabular}

表 3 に, 高度分析開発セクターの主な測定・分析装置を示 す。表面技術関連の分析依頼試験は化学計測分野で行ってい る。極表面の分析には, X 線光電子分光分析 (XPS) 装置やラ ザフォード後方散乱／弾性反跳粒子分析 (RBS/ERDA) 装置等 による分析依頼試験を実施している。また，極微量分析には， 誘導結合プラズマ(ICP) 質量分析装置等を用いている。

XPS においては皮膜の深さ方向分析が可能であるため, 各 種の複合皮膜等に有効である。

また, RBS/ERDA 装置においては軽元素の分析が可能で あるため, 炭素系の皮膜の水素分析などに利用可能である。

図 4 にRBS/ERDA 装置の試料室部分の外観を示す。図の手 前から試料を挿入し, 右方にある加速器からへリウムや窒素 などのイオンを照射する。水素分析の際には, 試料からはじ き出された水素原子を弾性反跳粒子検出器により捕捉する。

図 5 に, ダイヤモンド状炭素(DLC) 膜の含有水素を, 表面か ら皮膜内部へ深さ測定した例を示す。最表面では吸着物質等 の影響により水素の相対濃度が高くなっているが, 表面から の深さが $25 \mathrm{~nm}$ より深くなると，ほぼ $11 \mathrm{~mol} \%$ で一定となり， これを含有水素量とみなすことができる。DLC 膜においては, 含有水素量が硬さやその他の特性に大きく影響することがわ かっており, 本測定方法は産業応用においても重要な情報を 提供することができる ${ }^{6)}$ 。

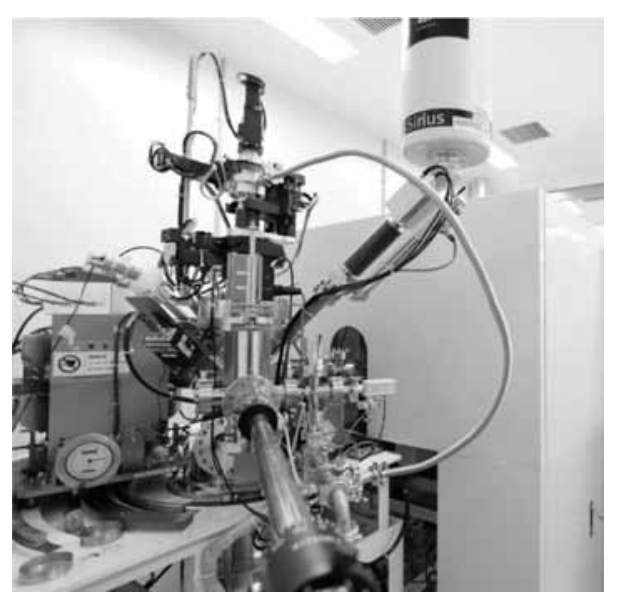

図 4 RBS/ERDA 分光分析装置 (試料室部分)

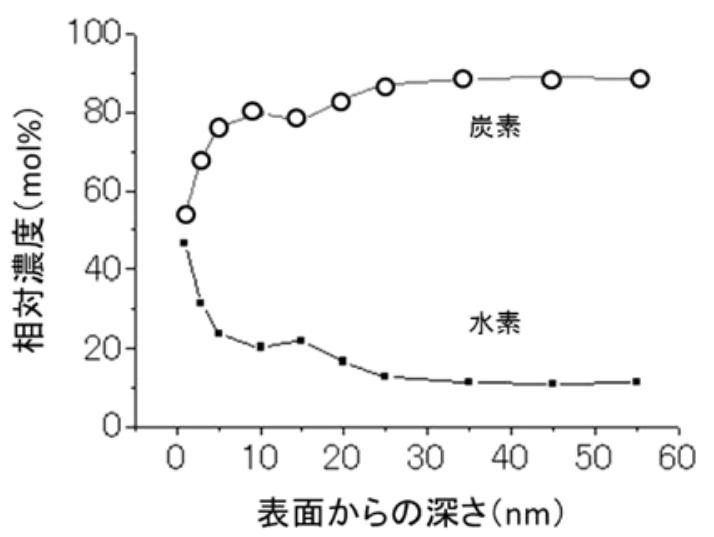

図 5 RBS/ERDA 分光分析装置による DLC 膜の水素定量事例 


\section{4.おわりに}

表面技術関連の分析依頼試験を中心に紹介したが，限られ たスペースやインフラを有効活用するために，電子顕微鏡群 などのように設置環境に制約があったり全所的に共同利用す ることが望ましい機器等については，専用室に集約して運用 の効率化を図っている。そのため, 試験項目と試験機器は必 ずしも一対一で対応しているわけではない。そのほか, 塩水 噴霧試験や耐候性試験等の環境試験については, 各支所や他 の部署でも一部実施している場合がある。なお，都産技研の 研究員は分析依頼試験とともに研究も行っており, もっぱら 研究用に用いる機器もある。表面技術グループの各分野では， 各種の表面改質装置やめっき装置，塗装ブースなどを用いて， 高耐久性付与や環境負荷低減に関する研究を行っている。こ れらについては, 共同研究や受託研究などの制度により利用 できる場合もある。詳細は都産技研ホームページを参照いた だきたい。

都産技研は平成 18 年度の独法化以来，様々なサービス改 善を行っており，対応可能な分析依頼試験の種類は格段に増 加した。定型的な分析依頼試験では対応が困難な場合のため に，オーダーメード試験やオーダーメード開発支援などの事 業メニューが用意されている。これらは，試験条件等につい て綿密な打ち合わせを行った後に実施している。今後も最新 技術への対応とともに，基盤的技術の伝承にも留意しながら 依頼試験等の技術支援をと抄して中小企業支援を実施してい く所存である。

\section{謝 辞}

写真等資料を提供いただきました経営企画部広報室に感謝 いたします。

\section{文献}

1 ）東京都産業労働局; 東京の産業と雇用就業2012,p.44 (2012)

2 ) (地独) 東京都立産業技術研究センター; 地方独立行政法人東京 都立産業技術研究センター平成24年度年報, p.3 (2013).

3 ）(地独) 東京都立産業技術研究センター; 平成23年度地方独立行 政法人東京都立産業技術研究センター業務実績報告書, p.5 (2013).

4 ）東京都立工業技術センター ; 東京都立工業技術センター二十年 史, p.1 (1991).

5 ) (地独) 東京都立産業技術研究センター; 地方独立行政法人東京 都立産業技術研究センター平成24年度年報, p.173 (2013).

6 ) 川口雅弘; TIRI News, 5 月号, p.6 ((地独) 東京都立産業技術研究 センター, 2012)

\section{著者連絡先}

(地独) 東京都立産業技術研究センター 事業化支援本部 地域技術支援部城東支所 三尾 淳

（₹ 125-0062＼cjkstart東京都葛飾区青戸 7-2-5）

開発本部 開発第二部 表面技術グループ 木下稔夫

（ ₹ 135-0064＼cjkstart東京都江東区青海 2-4-10）

事業化支援本部 技術開発支援部 高度分析開発セクター 上野博志 （₹ 135-0064＼cjkstart東京都江東区青海 2-4-10） 